\title{
Immunofluorescence Imaging Strategy for Evaluation of the Accessibility of DNA 5-Hydroxymethylcytosine in Chromatins
}

\author{
Shangwei Zhong, ${ }^{\dagger}$ Zhe Li, ${ }^{\ddagger}$ Ting Jiang, ${ }^{\dagger}$ Xiangjun $\mathrm{Li}^{*}{ }^{\dagger}{ }^{\dagger}$ and Hailin Wang ${ }^{*}, \S_{\odot}$ \\ ${ }^{\dagger}$ School of Chemistry and Chemical Engineering, University of Chinese Academy of Sciences, Beijing 100049, China \\ ${ }^{\ddagger}$ State Key Laboratory of Environmental Chemistry and Ecotoxicoogy, Research Center for Eco-Environmental Sciences, Beijing \\ 100085, China \\ ${ }^{\S}$ University of Chinese Academy of Sciences, Beijing 100049, China
}

\section{Supporting Information}

ABSTRACT: DNA 5-hydroxymethylcytosine (5hmC) is an important epigenetic modification found in various mammalian cells. Immunofluorescence imaging analysis essentially provides visual pictures for the abundance and distribution of DNA $5 \mathrm{hmC}$ in single cells. However, nuclear DNA is usually wrapped around nucleosomes, packaged into chromatins, and further bound with many functional proteins. These physiologically relevant events would generate barriers to the anti-5hmC antibody to selectively recognize $5 \mathrm{hmC}$ in DNA. By taking advantage of these naturally generated barriers, here, we present a strategy to evaluate the accessibility of DNA
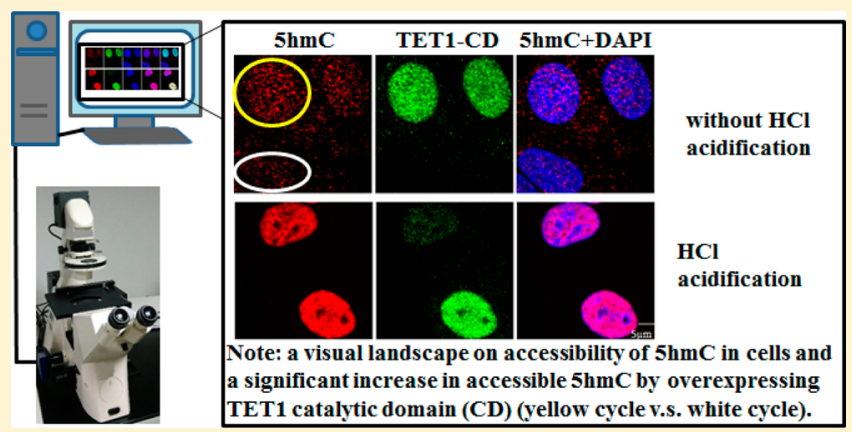
$5 \mathrm{hmC}$ in chromatins in situ. We demonstrate that a few of the $5 \mathrm{hmC}$ sites in DNA are exposed or accessible to anti-5hmC antibody under nondenaturing conditions, suggesting that these $5 \mathrm{hmC}$ sites are not covered by functional DNA-binding proteins in mouse embryonic stem cells. Consistently, these $5 \mathrm{hmC}$ foci were distributed in open euchromatin regions as revealed by the 4',6-diamidino-2-phenylindole (DAPI) staining. By overexpressing TET1 catalytic domain (responsible for oxidation $5 \mathrm{mC}$ to produce $5 \mathrm{hmC}$ ) in human MCF-7 cells, we observed a significant increase in accessible $5 \mathrm{hmC}$ along with an increase in total $5 \mathrm{hmC}$ sites. Collectively, by the use of the nondenaturing immunofluorescence imaging approach, we could obtain a visual landscape on the accessibility of DNA 5hmC in chromatins.

$\mathrm{D}$ NA 5-hydroxymethylcytosine $(5 \mathrm{hmC})$ is a key epigenetic modification and is derived from the oxidation of DNA 5methylcytosine $(5 \mathrm{mC})$ catalyzed by ten-eleven translocation (TET) family dioxygenases, including TET1, TET2, and TET3. ${ }^{1-4}$ The $5 \mathrm{hmC}$ can further be oxidized into 5formylcytosine (5fC) and 5-carboxylcytosine (5caC), which can be excised by thymine-DNA glycosylase (TDG) and replaced with unmethylated cytosine through a base-excision repair (BER) pathway. ${ }^{5-7}$ DNA $5 \mathrm{hmC}$ as an epigenetic marker may be involved in cellular differentiation and genome organization rather than only being involved in intermediate production in $5 \mathrm{mC}$ demethylation. ${ }^{8-10}$ Importantly, a line of accumulated evidence supports that the $5 \mathrm{hmC}$ abundance is significantly reduced in cancers. ${ }^{11-13}$ Interestingly, DNA 5hmC is also responsive to environmental stresses. ${ }^{3,4,14,15}$

A number of methods have been developed for $5 \mathrm{hmC}$ analysis, for example, liquid chromatography-mass spectrometry (LC-MS/MS) for digested genomic $\mathrm{DNA}^{1,3,4}$ and for urinary deoxynucleosides, ${ }^{16} 5 \mathrm{hmC}$-specific sequencing, ${ }^{17-20}$ and immunoassays. ${ }^{21-23}$ Immunoassays include anti-5hmC antibodies for specific recognition of $5 \mathrm{hmC}$ in DNA. Since the antibodies only specifically bind $5 \mathrm{hmC}$ in naked DNA, immunostaining for $5 \mathrm{hmC}$ imaging in cells often includes $\mathrm{HCl}$ treatment to release DNA from the bound proteins. Essentially, by the means of $\mathrm{HCl}$ treatment, $5 \mathrm{hmC}$ staining indeed increases significantly. ${ }^{13,22,24}$

Here, we reported an immunofluorescence imaging strategy to evaluate the DNA $5 \mathrm{hmC}$ accessibility in chromatins (Scheme $1)$. DNA is packed around nucleosomes, which are further organized to form chromatins. Chromatin organization is dynamic and governed by multiple factors. ${ }^{25-27}$ In addition, the DNA $5 \mathrm{hmC}$ is bound by its binders or readers such as UHRF2 and SALL4A. ${ }^{28,29}$ All these physiological events would generate various barriers to occlude anti-5hmC antibody from accessing $5 \mathrm{hmC}$ antigens in genomic DNA in three-dimensional nuclei. Therefore, if we think in a different way, by tuning the milieus, antibody binding (with $5 \mathrm{hmC}$ ) can be used to evaluate the accessibility of DNA $5 \mathrm{hmC}$ in cells. Essentially, chromatin accessibility is linked to transcriptional activity in combination with epigenetic modifications, including DNA methylation and hydroxymethylation. ${ }^{30-32}$

To show the principle-of-proof, we used mouse embryonic stem (ES) cells as an example. ES cells are pluripotent and maintain a globally open chromatin state; meanwhile, ES cells

Received: April 17, 2017

Accepted: May 14, 2017

Published: May 18, 2017 
Scheme 1. Different Accessibility of $5 \mathrm{hmC}$ in Chromatins ${ }^{a}$

(a)

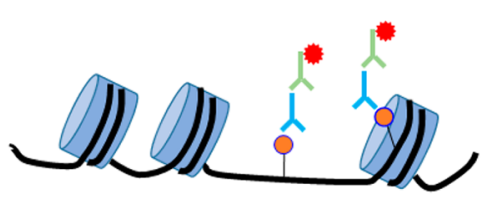

(b)

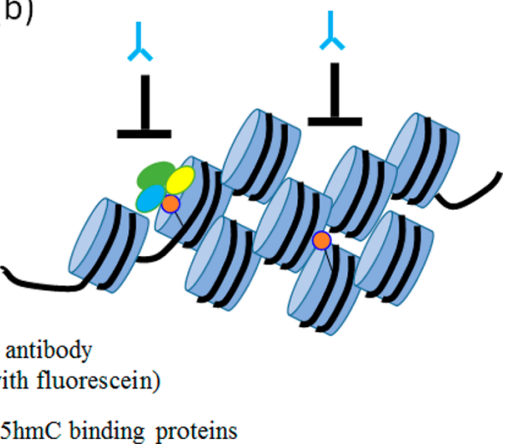

${ }^{a}(\mathrm{a})$ The $5 \mathrm{hmC}$ in open chromatin is more accessible; (b) the $5 \mathrm{hmC}$ protected by binding proteins or in condensed chromatin is sterically occluded from anti-ShmC antibody.

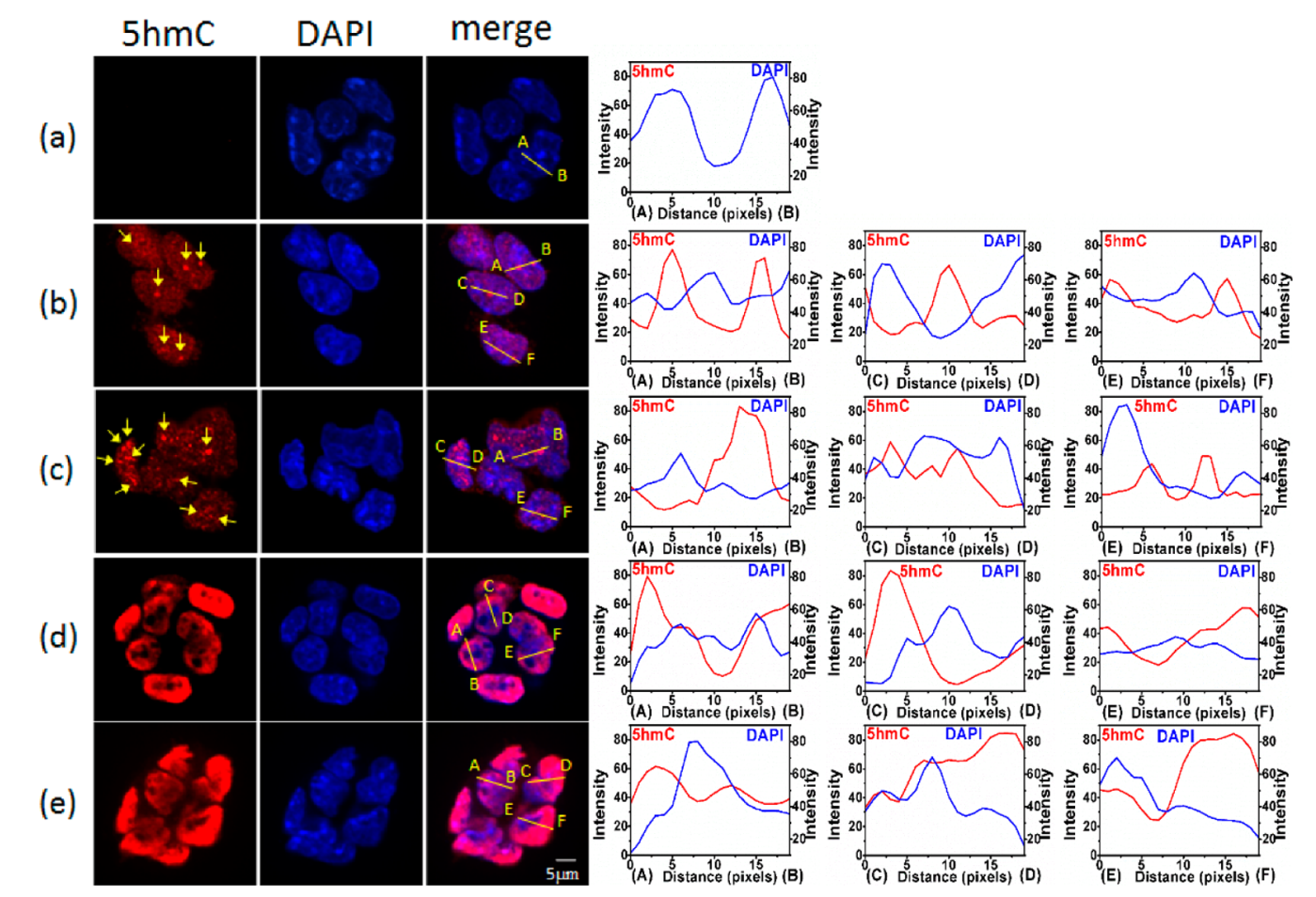

Figure 1. Accessibility of DNA $5 \mathrm{hmC}$ in chromatins of mouse ES cells. (a) Negative control, the cells were incubated with no 5 hmC primary antibody but with only second antibody. (b-e) The cells were pretreated with no $\mathrm{HCl}$ acidification (b), no $\mathrm{HCl}$ acidification but with $\mathrm{RNase}(\mathrm{c})$, $\mathrm{HCl}$ acidification (d), and both $\mathrm{HCl}$ acidification and RNase (e), respectively. Line scan graphs of 5hmC (red) and DAPI (blue) fluorescence intensities in the cells are shown (right). $5 \mathrm{hmC}$ foci were highlighted with yellow arrows. Left $y$ axis is shown for $5 \mathrm{hmC}$, and right $y$ axis is shown for DAPI.

contain abundant $5 \mathrm{hmC} .^{3,33}$ We treated the cells with or without $\mathrm{HCl}$ and $\mathrm{RNase}$ and observed the distinct distribution of $5 \mathrm{hmC}$ foci. Without $\mathrm{HCl}$ pretreatment, we could obtain a visual landscape of accessible $5 \mathrm{hmC}$ in cells, and with $\mathrm{HCl}$ pretreatment, we observed a distribution of global DNA 5hmC. We also examined the accessibility of newly generated DNA $5 \mathrm{hmC}$ in cells.

\section{EXPERIMENTAL SECTION}

Cell Culture. The culture of mES cells was performed according to our published approach. ${ }^{14}$ The human breast cancer cell line MCF-7 was cultured in DMEM (Gibco) medium, which was supplemented with $10 \%$ FBS (Corning), $100 \mathrm{U} / \mathrm{mL}$ penicillin, and $100 \mu \mathrm{g} / \mathrm{mL}$ streptomycin (Corning).
The cells were incubated in a humidified $37^{\circ} \mathrm{C}$ incubator with $5 \% \mathrm{CO}_{2}$

Construction of Plasmid and Transient Transfection. Human TET1 C-terminal catalytic domain (CD) was cloned into pIRES2-EGFP vector containing flag tag by PCR amplification. The constructed plasmid was subjected to DNA sequencing to ensure no mutations were introduced. MCF-7 cells were transiently transfected with constructed TET1-CD plasmid by lipofectamine 2000 (Invitrogen) following the manufacturer's guidelines.

Immunofluorescent Staining and Imaging Analysis. Cultured cells were plated onto glass-bottom dishes and stained following seven steps. (1) The cells were washed with PBS and fixed with $4 \%$ paraformaldehyde solution for 15 min followed by another PBS wash. (2) The cells were permeabilized with 


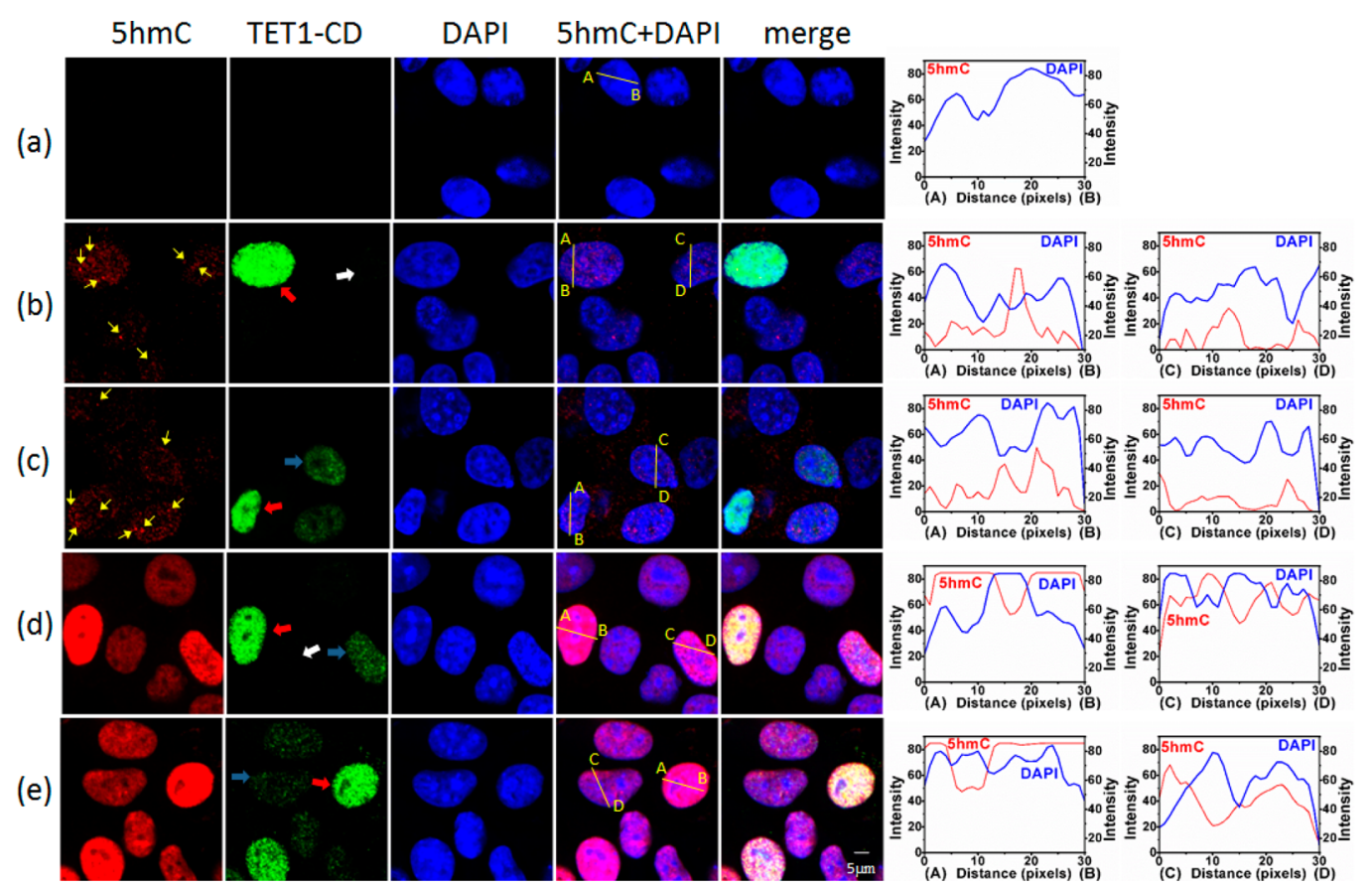

Figure 2. Immunofluorescence analysis of accessible DNA 5hmC in TET1-CD transfected MCF-7 cells. (a) Negative control, the cells were incubated with no anti-5 hmC and antiflag tag primary antibody but with only second antibodies; (b) the cells were pretreated with no $\mathrm{HCl}$ acidification; (c) no $\mathrm{HCl}$ acidification but with RNase; (d) $\mathrm{HCl}$ acidification; (e) both $\mathrm{HCl}$ acidification and RNase. Arrows indicate relatively high TET1-CD overexpressed (red arrow), low TET1-CD overexpressed (purple arrow), and no TET1-CD overexpressed (white arrow) cells. Line scan graphs of $5 \mathrm{hmC}$ (red) and DAPI (blue) fluorescence intensities in cells are shown (right). $5 \mathrm{hmC}$ foci were highlighted with yellow arrows. Of note, left $y$ axis is shown for $5 \mathrm{hmC}$, and right $y$ axis is shown for DAPI.

$0.1 \%$ Triton $\mathrm{X}-100$ for $10 \mathrm{~min}$ and further treated with RNase for $2 \mathrm{~h}$ at $37^{\circ} \mathrm{C}$. (3) The cells were incubated with $4 \mathrm{~N} \mathrm{HCl}$ for $15 \mathrm{~min}$ at room temperature (RT), rinsed with distilled water, and placed in $100 \mathrm{mM}$ Tris- $\mathrm{HCl}$ ( $\mathrm{pH} \mathrm{8.5)}$ for $10 \mathrm{~min} .{ }^{13}$ This step could denature dsDNA into ssDNA. (4) The cells were washed with PBS again, and a blocking solution (3\% goat serum in PBST) was applied for $1 \mathrm{~h}$ at RT. (5) The cells were incubated with diluted anti-5 hmC rabbit polyclonal $\mathrm{IgG}$ (Active Motif) antibody overnight at $4{ }^{\circ} \mathrm{C}$. (6) The dishes were washed with PBST solution and incubated with Alexa Fluor 555 conjugated goat antirabbit secondary antibody for $1 \mathrm{~h}$ at RT. (7) $4^{\prime}, 6$-Diamidino-2-phenylindole (DAPI) was finally applied to stain the nuclei for $10 \mathrm{~min}$. The steps are optional as indicated in the designed experiments, but the sequences of the procedures would not be changed. Of note, in order to detect 5hmC and TET1-CD (containing a flag-tag) simultaneously, the (5) step was modified by incubating with both anti-5hmC rabbit polyclonal IgG antibody and mouse monoclonal antiflag antibody for binding Tet1CD, and the (6) step was modified by utilizing both Alexa Fluor 555 conjugated goat antirabbit secondary antibody and Alexa Fluor488 conjugated goat antimouse secondary antibody. Fluorescence imaging was collected by confocal fluorescence microscopy (Olympus). Intensity of $5 \mathrm{hmC}$ immunofluorescence staining was analyzed by ImageJ software.

\section{RESULTS AND DISCUSSION}

First, we investigated the accessibility of $5 \mathrm{hmC}$ in mouse ES cells. We treated mouse ES cells with or without $\mathrm{HCl}$ acidification and RNase prior to $5 \mathrm{hmC}$ immuneostaining. Without $\mathrm{HCl}$ acidification of the mouse ES cells, we observed a considerable number of $5 \mathrm{hmC}$ foci, especially several noticeable fluorescent highlights (Figure 1b). Without the involvement of primary antibody (anti-5hmC antibody), only secondary antibody (fluorescently labeled) failed to generate these signals (Figure 1a). Since $5 \mathrm{hmC}$ base is also found in RNA, ${ }^{34,35}$ we further exploited RNase treatment, we still observed $5 \mathrm{hmC}$ foci (Figure 1c vs Figure 1b). Therefore, the observed $5 \mathrm{hmC}$ foci are not attributed to that in RNA. This is plausible because RNA contains much lower $5 \mathrm{hmC} .^{35}$ These foci locate in the regions of weak DAPI staining, which are usually considered as euchromatin-related regions (Figure $1 \mathrm{~b}, \mathrm{c}$ ). Although previous work showed that DNA $5 \mathrm{hmC}$ mainly distributed in euchromatin, our results indicate that the distribution of accessible $5 \mathrm{hmC}$ in chromatin is uneven and may tend to accumulate in some more open euchromatin regions. By the depletion of Tet $1 /$ Tet 2 , which are major enzymes responsible for oxidation of $5 \mathrm{mC}$ to form $5 \mathrm{hmC}$ in ES cells, we could not observe these $5 \mathrm{hmC}$ foci, confirming the link of the observed $5 \mathrm{hmC}$ with Tet $1 /$ Tet 2 oxidation activity (Figure S1). We also observed accessible DNA $5 \mathrm{hmC}$ foci in MCF-7 cells when undenatured staining was employed (without $\mathrm{HCl}$ acidification treatment) (Figure S2b,c).

By $\mathrm{HCl}$ acidification, most DNA $5 \mathrm{hmC}$ sites buried in chromatin or covered by binding proteins also became exposed. Thus, the DNA $5 \mathrm{hmC}$ signal significantly increased (Figure 1d). The signal became too strong to observe the single foci. Further RNase treatment did not reduce $5 \mathrm{hmC}$ signal (Figure $1 \mathrm{~d}$ vs Figure 1e). One of the reasons might be that the abundance of $5 \mathrm{hmC}$ in RNA is much lower than $5 \mathrm{hmC}$ in DNA. ${ }^{35,36}$ Moreover, RNA could also be degraded by $\mathrm{HCl}$ acidification. ${ }^{37,38}$ It is clear that $\mathrm{HCl}$ pretreatment can significantly improve staining efficiency for global DNA $5 \mathrm{hmC}$ because of increasing the exposure of DNA $5 \mathrm{hmC}$ antigens through denaturing DNA. By such staining, we could also observe bright $5 \mathrm{hmC}$ signal in heterochromatin regions (as 
indicated by DAPI staining-related deep blue). Well immunofluorescent signals of DNA $5 \mathrm{hmC}$ were also observed in MCF7 cells after $\mathrm{HCl}$ acidification pretreatment (Figure S2).

Now, we turned our attention to newly formed $5 \mathrm{hmC}$ sites in cultured cells. It is not known whether these new $5 \mathrm{hmC}$ sites are more accessible or protected immediately after the occurrence. For this purpose, we transfected MCF-7 cells with a plasmid carrying TET1-CD. MCF-7 cells belong to the family of breast cancer, which is one commonly diagnosed cancer in females. Many affected female patients die from this lethal cancer despite better diagnosis and therapy dramatically improving survival. ${ }^{39,40}$ Without $\mathrm{HCl}$ acidification of the cells, we observed a significant increase in $5 \mathrm{hmC}$ in the cells overexpressing TET1-CD (indicated by red arrows, Figure 2b) and much less $5 \mathrm{hmC}$ in the cells absent of transfected TET1$\mathrm{CD}$ (indicated by white arrow, Figure 2b). After RNase treatment, these $5 \mathrm{hmC}$ foci were stilled observed (Figure $2 \mathrm{c}$ ). The results suggest that with the introduction of newly generated $5 \mathrm{hmC}$ sites more accessible $5 \mathrm{hmC}$ sites were observed. Meanwhile, with the $\mathrm{HCl}$ acidification of the cells, compared with low TET1-CD overexpressed cells (Figure 2d, purple arrow), the $5 \mathrm{hmC}$ staining also increased significantly in high TET1-CD overexpressed MCF-7 cells (Figure 2d, red arrows). Of note, by the $\mathrm{HCl}$ acidification, there is little difference for the $5 \mathrm{hmC}$ staining between the two cases with and without RNase (Figure 2d vs Figure 2e). Consistently, $5 \mathrm{hmC}$ could also be observed in heterochromatin regions (indicated by deep blue).

\section{CONCLUSION}

In summary, we presented a novel immunofluorescence imaging strategy to analyze the abundance and accessibility of $5 \mathrm{hmC}$ in DNA in single cells. Our results showed that $\mathrm{HCl}$ acidification treatment is a crucial step to selectively indicate global DNA $5 \mathrm{hmC}$ by immunofluorescence staining. However, without $\mathrm{HCl}$ acidification, we are able to obtain the visual picture for evaluation of the $5 \mathrm{hmC}$ accessibility in cultured cells.

\section{ASSOCIATED CONTENT}

\section{S Supporting Information}

The Supporting Information is available free of charge on the ACS Publications website at DOI: 10.1021/acs.analchem. 7 b01428.

The $5 \mathrm{hmC}$ staining images for Tet $1 /$ Tet 2 knockout cells and for the evaluation of accessibility of DNA $5 \mathrm{hmC}$ in MCF-7 cells (PDF)

\section{AUTHOR INFORMATION}

\section{Corresponding Authors}

*E-mail: hlwang@rcees.ac.cn (H.W.).

*E-mail: lixiangj@ucas.ac.cn (X.L.).

\section{ORCID}

Hailin Wang: 0000-0002-1843-999X

Notes

The authors declare no competing financial interest.

\section{ACKNOWLEDGMENTS}

This work is supported by the Ministry of Science and Technology of China (2016YFC0900300), the National Natural Science Foundation of China (21327006, 21435008, and 21621064), and the Strategic Priority Research Program of the Chinese Academy of Sciences (XDB14030200).

\section{REFERENCES}

(1) Tahiliani, M.; Koh, K. P.; Shen, Y. H.; Pastor, W. A.; Bandukwala, H.; Brudno, Y.; Agarwal, S.; Iyer, L. M.; Liu, D. R.; Aravind, L.; Rao, A. Science 2009, 324, 930-935.

(2) Wang, J. Y.; Tang, J.; Lai, M. D.; Zhang, H. H. Mutat. Res., Rev. Mutat. Res. 2014, 762, 167-175.

(3) Yin, R. C.; Mao, S. Q.; Zhao, B. L.; Chong, Z. C.; Yang, Y.; Zhao, C.; Zhang, D. P.; Huang, H.; Gao, J.; Li, Z.; Jiao, Y.; Li, C. P.; Liu, S. Q.; Wu, D. N.; Gu, W. K.; Yang, Y. G.; Xu, G. L.; Wang, H. L. J. Am. Chem. Soc. 2013, 135, 10396-10403.

(4) Zhao, B. L.; Yang, Y.; Wang, X. L.; Chong, Z. C.; Yin, R. C.; Song, S. H.; Zhao, C.; Li, C. P.; Huang, H.; Sun, B. F.; Wu, D. N.; Jin, K. X.; Song, M. Y.; Zhu, B. Z.; Jiang, G. B.; Danielsen, J. M. R.; Xu, G. L.; Yang, Y. G.; Wang, H. L. Nucleic Acids Res. 2014, 42, 1593-1605.

(5) Ito, S.; Shen, L.; Dai, Q.; Wu, C. S.; Collins, L. B.; Swenberg, J. A.; He, C.; Zhang, Y. Science 2011, 333, 1300-1303.

(6) He, Y. F.; Li, B. Z.; Li, Z.; Liu, P.; Wang, Y.; Tang, Q. Y.; Ding, J. P.; Jia, Y. Y.; Chen, Z. C.; Li, L.; Sun, Y.; Li, X. X.; Dai, Q.; Song, C. X.; Zhang, K. L.; He, C.; Xu, G. L. Science 2011, 333, 1303-1307.

(7) Wu, S. C.; Zhang, Y. Nat. Rev. Mol. Cell Biol. 2010, 11, 607-620.

(8) Yamaguchi, S. P.; Hong, K.; Liu, R.; Inoue, A.; Shen, L.; Zhang, K.; Zhang, Y. Cell Res. 2013, 23, 329-339.

(9) Kroeze, L. I.; Reijden, B. A.; Jansen, J. H. Biochim. Biophys. Acta, Rev. Cancer 2015, 1855, 144-154.

(10) Iqbal, K.; Jin, S. G.; Pfeifer, G. P.; Szabó, P. E. Proc. Natl. Acad. Sci. U. S. A. 2011, 108, 3642-3647.

(11) Haffner, M. C.; Chaux, A.; Meeker, A. K.; Esopi, D. M.; Gerber, J.; Pellakuru, L. G.; Toubaji, A.; Argani, P.; Iacobuzio-Donahue, C.; Nelson, W. G.; Netto, G. J.; De Marzo, A. M.; Yegnasubramanian, S. Oncotarget 2011, 2, 627-637.

(12) Kroeze, L. I.; van der Reijden, B. A.; Jansen, J. H. Biochim. Biophys. Acta, Rev. Cancer 2015, 1855, 144-154.

(13) Sajadian, S. O.; Ehnert, S.; Vakilian, H.; Koutsouraki, E.; Damm, G.; Seehofer, D.; Thasler, W.; Dooley, S.; Baharvand, H.; Sipos, B.; Nussler, A. K. Clin. Epigenet. 2015, 7, 98.

(14) Li, C. P.; Liu, B. D.; Zhong, S. W.; Wang, H. L. Oncotarget 2016, 7, 39730-39739.

(15) Li, C.; Wang, F. B.; Wang, H. L. J. Environ. Sci. (Beijing, China) 2017, 51, 5-12.

(16) Yin, R. C.; Mo, J. Z.; Lu, M. L.; Wang, H. L. Anal. Chem. 2015, $87,1846-1852$

(17) Xu, Y.; Wu, F.; Tan, L.; Kong, L.; Xiong, L.; Deng, J.; Barbera, A. J.; Zheng, L.; Zhang, H.; Huang, S.; Min, J.; Nicholson, T.; Chen, T.; Xu, G.; Shi, Y.; Zhang, K.; Shi, Y. G. Mol. Cell 2011, 42, 451-464.

(18) Han, D.; Lu, X. Y.; Shih, A. H.; Nie, J.; You, Q. C.; Xu, M. M.; Melnick, A. M.; Levine, R. L.; He, C. Mol. Cell 2016, 63, 711-719.

(19) Gan, H.; Wen, L.; Liao, S.; Lin, X.; Ma, T.; Liu, J.; Song, C. X.; Wang, M.; He, C.; Han, C.; Tang, F. Nat. Commun. 2013, 4, 1995.

(20) Zhao, C.; Wang, H. L.; Zhao, B. L.; Li, C. P.; Yin, R. C.; Song, M. Y.; Liu, B. D.; Liu, Z.; Jiang, G. B. Nucleic Acids Res. 2014, 42, e81.

(21) Nestor, C. E.; Ottaviano, R.; Reddington, J.; Sproul, D.; Reinhardt, D.; Dunican, D.; Katz, E.; Dixon, J. M.; Harrison, D. J.; Meehan, R. R. Genome Res. 2012, 22, 467-477.

(22) Kafer, G. R.; Li, X.; Horii, T.; Suetake, I.; Tajima, S.; Hatada, I.; Carlton, P. M. Cell Rep. 2016, 14, 1283-1292.

(23) Yang, H. L. Y.; Bai, F.; Zhang, J. Y.; Ma, S. H.; Liu, J.; Xu, Z. D.; Zhu, H. G.; Ling, Z. Q.; Ye, D.; Guan, K. L.; Xiong, Y. Oncogene 2013, 32, 663-669.

(24) Ito, S.; D’Alessio, A. C.; Taranova, O. V.; Hong, K.; Sowers, L. C.; Zhang, Y. Nature 2010, 466, 1129-1133.

(25) Kaplan, N.; Moore, I. K.; Fondufe-Mittendorf, Y.; Gossett, A. J.; Tillo, D.; Field, Y.; LeProust, E. M.; Hughes, T. R.; Lieb, J. D.; Widom, J.; Segal, E. Nature 2009, 458, 362-366.

(26) Bell, O.; Tiwari, V. K.; Thoma, N. H.; Schubeler, D. Nat. Rev. Genet. 2011, 12, 554-564. 
(27) Talbert, P. B.; Henikoff, S. Nat. Rev. Mol. Cell Biol. 2010, 11, 264-275.

(28) Spruijt, C. G.; Gnerlich, F.; Smits, A. H.; Pfaffeneder, T.; Jansen, P. W. T. C.; Bauer, C.; Munzel, M.; Wagner, M.; Muller, M.; Khan, F.; Eberl, H. C.; Mensinga, A.; Brinkman, A. B.; Lephikov, K.; Muller, U.; Walter, J.; Boelens, R.; van Ingen, H.; Leonhardt, H.; Carell, T.; Vermeulen, M. Cell 2013, 152, 1146-1159.

(29) Xiong, J.; Zhang, Z. Q.; Chen, J. Y.; Huang, H.; Xu, Y. L.; Ding, X. J.; Zheng, Y.; Nishinakamura, R.; Xu, G. L.; Wang, H. L.; Chen, S.; Gao, S. R.; Zhu, B. Mol. Cell 2016, 64, 913-925.

(30) Kim, K.; Ban, H. J.; Seo, J.; Lee, K.; Yavartanoo, M.; Kim, S. C.; Park, K.; Cho, S. B.; Choi, J. K. Genome Biol. 2014, 15, R72.

(31) Degner, J. F.; Pai, A. A.; Pique-Regi, R.; Veyrieras, J. B.; Gaffney, D. J.; Pickrell, J. K.; De Leon, S.; Michelini, K.; Lewellen, N.; Crawford, G. E.; Stephens, M.; Gilad, Y.; Pritchard, J. K. Nature 2012, 482, 390-394.

(32) Ficz, G.; Branco, M. R.; Seisenberger, S.; Santos, F.; Krueger, F.; Hore, T. A.; Marques, C. J.; Andrews, S.; Reik, W. Nature 2011, 473, 398-402.

(33) Gaspar-Maia, A.; Alajem, A.; Meshorer, E.; Ramalho-Santos, M. Nat. Rev. Mol. Cell Biol. 2011, 12, 36-47.

(34) Zhang, H. Y.; Xiong, J.; Qi, B. L.; Feng, Y. Q.; Yuan, B. F. Chem. Commun. 2016, 52, 737-740.

(35) Fu, L. J.; Guerrero, C. R.; Zhong, N.; Amato, N. J.; Liu, Y. H.; Liu, S.; Cai, Q.; Ji, D. B.; Jin, S. G.; Niedernhofer, L. J.; Pfeifer, G. P.; Xu, G. L.; Wang, Y. S. J. Am. Chem. Soc. 2014, 136, 11582-11585.

(36) Xu, Q.; Wang, K.; Wang, L. N.; Zhu, Y. T.; Zhou, G. Y.; Xie, D.; Yang, Q. K. PLoS One 2016, 11, e0161261.

(37) Jarvinen, P.; Oivanen, M.; Lonnberg, H. J. Org. Chem. 1991, 56, 5396-5401.

(38) Oivanen, M.; Kuusela, S.; Lonnberg, H. Chem. Rev. 1998, 98, 961-990.

(39) Marcotte, R.; Sayad, A.; Brown, K. R.; Sanchez-Garcia, F.; Reimand, J.; Haider, M.; Virtanen, C.; Bradner, J. E.; Bader, G. B.; Mills, G. B.; Pe'er, D.; Moffat, J.; Neel, B. G. Cell 2016, 164, 293-309.

(40) Justo, N.; Wilking, N.; Jonsson, B.; Luciani, S.; Cazap, E. Oncologist 2013, 18, 248-256. 